\title{
Critical Analysis of Principal's Leadership Style on Primary School Teacher Performance
}

\author{
Rajim $^{1}$, Tukiran Taniredja ${ }^{2}$ \\ $\left\{\right.$ jimmy70@gmail.com ${ }^{1}$, tukiranump@gmail.com $\left.{ }^{2}\right\}$ \\ ${ }^{1,2}$ Magister Pendidikan Dasar, Universitas Muhammadiyah Purwokerto
}

\begin{abstract}
This research is about the Leadership Style of Principals in Elementary Schools. The problems studied were 1) How to implement the Principal's Leadership Style. 2) Constraints on Principal Leadership Style Implementation. 3). Critical Analysis of Principal's Leadership Style. In carrying out their duties, each principal uses different strategies and methods according to his character, which is known as the type and style of leadership. The purpose of this study was to determine the principal's leadership style in improving the performance of elementary school educators. The method used in this research is a qualitative method with a case study technique. Using secondary data types. The data obtained were collected, analyzed, and concluded to get conclusions about the literature study. Based on the research results, literature studies from several research results and journal articles show that the principal's leadership style is democratic, this can be seen from the role of the principal as an educator.
\end{abstract}

Keywords: principal leadership style, educator performance

\section{Introduction}

Education management or school management cannot be separated of the model or leadership style adopted by the principal in carry out their role as a leader. Adopted leadership style by the principal will be related to the results and effectiveness of the principal in leading and carrying out the educational process in schools. As stated by A. Glatthorn that "There is a strong attachment between the educational process in schools and the style and type of leadership used by the principal with the overall effectiveness in the school organization". That is, reliable human resources cannot be separated from the influence of patterns or styles and types of leadership applied in an organization, this will be reflected in the implementation of the organization. The style and type of good leadership can be seen in the running of the organization's wheels with discipline, orderly, comfortable, conducive and in accordance with the goals to be achieved [1] .

The performance of educators in schools has an important role in achieving school goals. Educators are one of the human resources (HR) in schools. Performance problems are in the spotlight of various parties, the government's performance will be felt by the community and the performance of educators will be felt by students or parents of students. Various efforts were made to achieve good performance. In addition to educators, school management factors, which in this case are commanded by school principals, also determine the level of quality of education. The principal in the education unit is a leader or manager. The principal has two positions and an important role in carrying out the educational process in his institution. First, the principal as the manager of education in the school, and second, the principal as the formal leader of education in the school [2]. 
The principal is responsible for the leadership of small-scale education, which is directly related to the learning process. Basically school leadership is the responsibility of the principal and educators. However, good management cannot be separated from the influence of the principal's role in leading the school system on the implementation of good management as well [3].

The principal's leadership will be accepted by teachers if the leadership applied is very suitable and liked by the teachers. So if it is so, the teacher will have a tendency to improve his performance. Principal leadership who can utilize resources and especially human resources, namely teachers, will in turn improve teacher performance and the overall result achieved is the quality of education [4]

Leadership is a process that contains elements of influencing, cooperating and leading to something and a goal together in an organization. Because leadership has a role central to the dynamics of organizational life. In that case, Headmaster is an educational leader who is very dependent on how the skills and wisdom of the principal in leading a school or sponsored institution. A principal must be able to give effect charismatic leadership, can set an example, can move and directing all school stakeholders to be able to achieve the desired goals want to achieve. As stated by Hendiyat Suetopo and Wasty Suemanto that "The main function of the principal as an educational leader is to create a teaching and learning situation so that teachers can teach and students can learn well"[5]. The ability of a principal in leading is very influential in improving the work of teachers as well as improving and creating an appropriate (effective) and targeted learning process. The leadership style applied by the principal will affect the process of creating comfort, orderliness in the learning process, especially on teacher work discipline and teacher performance [6]

According to Elly and Soraya, principal's leadership style is very well and partially significant on teacher performance[7]. The school environment also has a positive and partially significant effect on teacher performance; and principal leadership style and school environment have a good and significant effect simultaneously on teacher performance.

In every leader has a leadership style and type. There are times when the leader does not give his subordinates an opportunity (ignore). Then, the leader gives subordinates the opportunity to discuss or give each other input, ask questions (Democratic). Besides, there are leaves the conditions up to his subordinates (Laissez-fair). Research findings indicate that leadership is aimed at task completion or goal orientation (Initiating Structure), and recognition of individual and relationship needs (Consideration). Furthermore, research continued by The Early Michigan Leadership Study showed that the leadership style is attention to employees (employee-centered) and also attention to the production process (production-centered)[8].

The leadership style applied by the principal can influence the creation and achievement of school goals to be achieved. There are various kinds of leadership styles applied by principals, there are leaders who apply authoritarian leadership styles and this tends to be responded negatively by their subordinates by showing low levels of work performance and productivity. In a more positive approach, leadership styles can be applied in a directive, supportive and participatory way. These three leadership styles can be applied in a balanced and simultaneously in a leadership process. A balanced portion of this leadership style will encourage the creation of work performance or productivity among teachers. [9]

\section{Research Method}

This research is a qualitative research with case study technique. Qualitative research is a type of research whose findings are not obtained through statistical procedures or other forms of calculation and seeks to understand and interpret the meaning of an event of human behavior 
interaction in certain situations according to the researcher's own perspective. are secondary data. Secondary data is data taken not from direct observers but from the results of research by previous researchers. This data collection method uses the documentation method. The documentation method is a systematic data collection procedure for reviewing both printed and electronic documents [6]. The documentation method is a method of collecting data by searching for or digging data from the literature related to what is intended in the formulation of the problem. Annotation means a simple conclusion from an article, book, journal, or some other written source, while a bibliography is defined as a list of sources on a topic [3].

\section{Result and Discussion}

Leadership is the process of influencing other people in an organization to achieve the goals and common interests of an organization. That is, success or failure in achieving organizational goals is largely determined by a person's leadership style in managing existing resources. And, it is from this leadership style that the atmosphere of the work environment is determined. Meanwhile, the principal is a teacher who meets certain requirements so that he can be given an additional task to lead a school, namely as the principal [10]

The strong character possessed by the leader will also have a positive influence on the style and success of his leadership. Therefore in determining the type and character of the leader must be observed and assessed properly. The following are factors that contribute to the success of an institution. Factors that influence the success and failure of leadership in developing a led institution can be measured or marked by four things, namely: morale, discipline, spirit of initiative (esprit de corps), and self-competence [9]

Employee performance is a measure that can be used to determine the comparison of the results of the implementation of tasks, responsibilities given by the organization in a certain period and relatively can be used to measure work performance or organizational performance [11]. The performance or work performance of an employee is basically the result of an employee's work during a certain period of time compared to various possibilities, for example standards, targets or other criteria that have been determined in advance and have been mutually agreed upon[10]. Performance or work performance is the quality and quantity of work achieved by an employee in carrying out his duties in accordance with the responsibilities assigned to him. Based on some of the definitions above, employee performance can be concluded as the output or work of employees in accordance with their duties and responsibilities to achieve organizational goals [11]

To improve the performance of education personnel, it is best to apply a daily journal system to administrative staff and library staff in order to facilitate monitoring / supervision of the performance of these educational personnel. To improve the discipline of teachers and education personnel, the principal should apply a reward and punishment system. To facilitate school management and achieve the school's vision and mission, it is better to immediately make School Development Plans (RPS) and strategic plans. [12-13]

\section{Conclusion}

Based on the background description and literature review, an appropriate alternative to overcome the low performance of teachers is the type and leadership style of the principal in carrying out his leadership required to be able to move teachers, students and school members to always improve their abilities so that academic and non-academic achievement results can increase.Principals have high commitment and motivation to advance. But in reality, most of the principals in the Sudirman general cluster are still low in their leadership style, so this will affect the performance of teachers in their respective schools. 
Simultaneously, leadership style and organizational culture have a positive and significant effect on employee performance. Partially, leadership style has an effect on employee performance but not significant. Partially organizational culture has a positive and significant effect on employee performance.

The leadership of the principal has a democratic-monarchical leadership style. This is based on the system that applies in the policy-making process and the decision-making process is carried out jointly, the role of the principal includes several aspects that have been implemented, namely: as an educator (educator), as a manager, as an administrator, as a supervisor, as a leader, as an innovator, as a very good motivator so that the principal can be an example in carrying out his duties. The strong character possessed by the leader will also have a positive influence on the style and success of his leadership. Therefore in determining the type and character of the leader must be observed and assessed properly. [10]

\section{References}

[1] Glatthorn AA, Joyner RL. Writing the winning thesis or dissertation: A step-by-step guide. Corwin Press; 2005 Mar 16..

[2] Hidayat A, Machali I. Pengelolaan pendidikan: konsep, prinsip, dan aplikasi dalam mengelola sekolah dan madrasah..

[3] E.Mulyasa, 2007.Standar Kompetensi dan Sertifikasi Guru. Bandung: PT. Remaja Rosdakarya.

[4] Fitri Asterina, Sukoco (2019).Pengaruh Kepemimpinan Kepala Sekolah, Motivasi Kerja, dan Disiplin Guru terhadap Kinerja Guru. Jurnal Akuntabilitas Manajemen Pendidikan. 2019 September;7(2),208-219

[5] Hendiyat Sutopo dan Wasty Soemanto, 1982.Kepemimpinan dan Supervisi Pendidikan. Malang: Bina Aksara.

[6] Thoyib A. Hubungan Kepemimpinan, Budaya, Strategi, dan Kinerja: Pendekatan Konsep. Jurnal manajemen dan kewirausahaan. 2005 May 2;7(1):60-73. Kristen Petra Siwalankerto 121-131 Surabaya 60236, Indonesia.

[7] Elly Y, Soraya J. Kepemimpinan Kepala Sekolah dan Lingkungan Sekolah terhadap Kinerja Guru. Jurnal Penelitian Dan Pendidikan IPS. 2020 Sep 22;14(2):55-61.

[8] Luthans F. The need for and meaning of positive organizational behavior. Journal of Organizational Behavior: The International Journal of Industrial, Occupational and Organizational Psychology and Behavior. 2002 September;23(6):695-706.

[9] Octavia LS, Savira SI. Gaya kepemimpinan kepala sekolah dalam upaya meningkatkan kinerja guru dan tenaga kependidikan. JDMP (Jurnal Dinamika Manajemen Pendidikan). 2017 Feb 7;1(1):7-14.

[10] Trang DS. Gaya kepemimpinan dan budaya organisasi pengaruhnya terhadap kinerja karyawan. Jurnal EMBA: Jurnal Riset Ekonomi, Manajemen, Bisnis Dan Akuntansi. 2013 Jul 8;1(3).

[11] Gibson CB, Birkinshaw J. The antecedents, consequences, and mediating role of organizational ambidexterity. Academy of management Journal. 2004 Apr 1;47(2):20926.

[12] Minsih M, Rusnilawati R, Mujahid I. Kepemimpinan Kepala Sekolah Dalam Membangun Sekolah Berkualitas Di Sekolah Dasar. Profesi Pendidikan Dasar. 2019 Jul 30;6(1):29-40.

[13] Yuliandri J, Kristiawan M. Peran Kepemimpinan Kepala Sekolah Terhadap Peningkatan Kinerja Guru. Jurnal Dosen Universitas PGRI Palembang. 2017 May 9. 